\title{
Experience with Lateral Upper Arm Flaps
}

\author{
熊本機能病院整形外科 \\ 中 島 英 親・平 野 哲 也 \\ 山本満・嶋 村 佳 雄 \\ 米満 弘之
}

\author{
Experience with Lateral Upper Arm Flaps \\ by \\ Hidechika Nakashima, Tetsuya Hirano, Mitsuru Yamamoto, \\ Yoshio Shimamura and Hiroyuki Yonemitsu \\ Department of Orthopedic Surgery Unit \\ Kumamoto Kinoh Hospital Kumamoto, 860
}

We studied 10 cadavers with lateral upper arm flaps.

All cadavers had the posterior radial collateral artery and accompanying vein and the posterior cutaneous nerve in the flap.

The diameter of the arteries averaged $1.47 \mathrm{~mm}$, and of the accompanying veins was $1.72 \mathrm{~mm}$.

Lateral upper arm flaps were used in 3 clinical cases to cover skin defects of the hand. All three flaps had a $100 \%$ survival rate.

Key words ; Lateral Upper Arm Flap, Microsurgery, Free flap

\section{はじめに}

Microsurgery の発達により種々の Free Flap が発 見され，骨付皮弁，筋皮弁，皮弁のみとして使用され ている。しかし皮弁の面積，皮弁の知賞，皮弁採取の 困難さ，皮弁採取後の donor 側問題等は recipient 側 の条件でかわってくる. Lateral Upper Arm Flap は 1982 年 $S o n g^{33}$ により発見され, 1983 年 Matloub, 1984 年 Katsaros ${ }^{1}$ によって詳細報告されている。この皮弁 は知覚神経を含めた皮弁で皮弁の面積は大きくとれな いが血管走行は解剖学的に異常が少ないという特徴が ある。今回私達は 10 例の Cadaver と 3 例の症例につ いて検討したので報告する.

\section{皮 弁 採 取}

上腕骨外顆と三角筋停止部を結んだ線を中心とし て, 外顆より中枢 $2 \sim 3 \mathrm{~cm}$ のところから三角筋停止 部の間に皮弁をデザインした、デザインした皮弁の前
面から切開し, 上腕三頭筋の Lateral head 下を通り, 外側上顆より約 $10 \mathrm{~cm}$ 中枢のところで筋間中隔をつ らぬき枝を出す，Posterior Radial Collateral Artery (以下 PRCA と略す) 確認する。私はこの前に筋間 中隔をつらぬいて上腕筋と腕橈骨筋の間を走行する Radial Nerve を確認し,これを中枢に剥離し筋間中隔

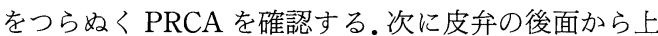
腕三頭筋の筋膜を皮弁につけて剥離することにしてい る。この皮弁を支配する神経として Posterior Cutaneous Nerve of Arm (以下PCNA と略す) と Posterior Cutaneous Nerve of forearm（以下 PCNF と略す）の 2 つがあり PCNA が PRCA と伴走する場 合は 10 例の Cadaver 中 6 例であった。

\section{対 象 症 例}

Cadaver 10 例, 臨床 3 例を対象とした. Cadaver は すべて 60 歳以上で女性 3 例, 男性 7 例であった。これ らの 10 例に上腕骨外顆と三角筋停止部を結んだ線を 
中心に外顆より中枢 $2 \sim 3 \mathrm{~cm}$ のところから三角停止 部の間にほぼ $5 \times 7 \mathrm{~cm}$ のデザインをし, 皮弁を挙上 した. 臨床 3 例は 50 歳男性, 60 歳女性, 57 歳女性で それぞれ $4 \times 8 \mathrm{~cm}, 4 \times 7 \mathrm{~cm}, 5 \times 12 \mathrm{~cm}$, の皮弁を 採取し, 母指内転拘縮 2 例, 手掌部皮膚欠損 1 例に移 植した。

\section{結果}

10 例の Cadaverの PRCA の動脈径は最大 1.8 $\mathrm{mm}$, 最小 $1.0 \mathrm{~mm}$ で平均 $1.72 \mathrm{~mm}$ であった。 皮弁を 支配するPRCA と伴走静脈はすべてに存在した。 PRCA に関しては皮弁に枝を出し皮弁の中を走行す る場合と皮弁に $1 \sim 2$ 本の枝を出し皮弁から離れて肘 のほうへ走行する場合があった，皮弁を支配する神経 に関しては，PCNAが PRCA と伴走して走行するも のが 10 例中 6 例であった. PRCA, PCNA の走行から 分類すると図Iのようになる. PCNA と PRCA が伴 走し, PRCA が皮弁の中を走行するもの 4 例, PCNA と PRCA が離れて皮弁に入り, PRCA が皮弁の中を 走行するもの 2 例, PCNA と PRCA が離れて皮弁に 入り，PRCA が皮弁に枝をだすもの 2 例，PCNA， PRCA が伴走し PRCA が皮弁に枝をだすもの 1 例, PCNA と PRCA が離れて皮弁に入り, PRCA が皮弁
に 2 本の枝を出すもの 1 例であった。 5 つの Type に 分類できた。臨床としては 3 例に用い皮弁の大きさは $4 \times 8 \mathrm{~cm}, 4 \times 7 \mathrm{~cm}, 5 \times 12 \mathrm{~cm}$ で donor 側は直接 縫合でき, 前腕外側に知覚低下とシビレの訴えが 2 例 にあるも支障はなかった。動脈径も $1.2 \mathrm{~mm}, 1.5 \mathrm{~mm}$. $1.8 \mathrm{~mm}$ と大きく, 吻合に問題はなかった.

症例

66 歳女性 (図 II)

平成 3 年 5 月 24 日, 機械にて受傷し, 某医で有茎の groin flap などの治療をうけ, 平成 4 年 1 月 31 日に右 手指拘縮, 右母指内転拘縮を生じたため紹介されて来 院する. 右手指拘縮に対して指間形成，伸筋腱痖着剝 離など施行後, 平成 4 年 7 月 16 日に $4 \times 7 \mathrm{~cm}$ の Lateral Upper Arm flap を施行した. 皮弁は完全生 着した。やや bulkyであるが母指と手指の指関部が拡 大し，大きなものが把持できるようになり日常生活で 使用している.

\section{考察}

Free Flap の種類は増加しているが，どれも十分と いえない. 手指の皮膚欠損，母指の内転拘縮のように 比較的小さな面積の場合, 私達はVenous Skin $\mathrm{Graft}^{2)}$
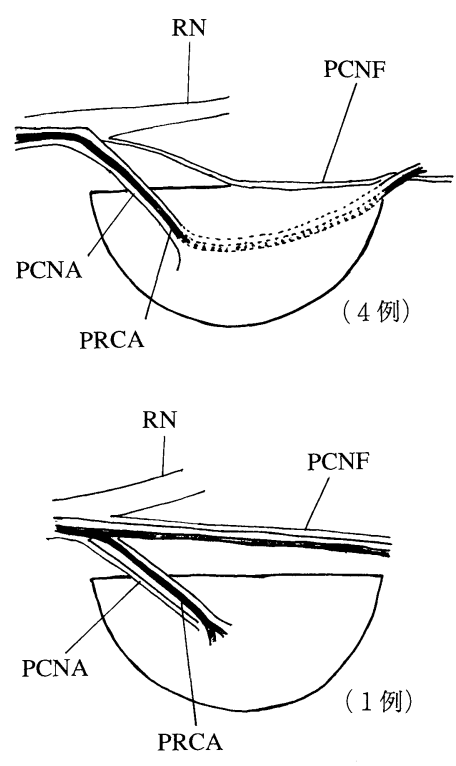
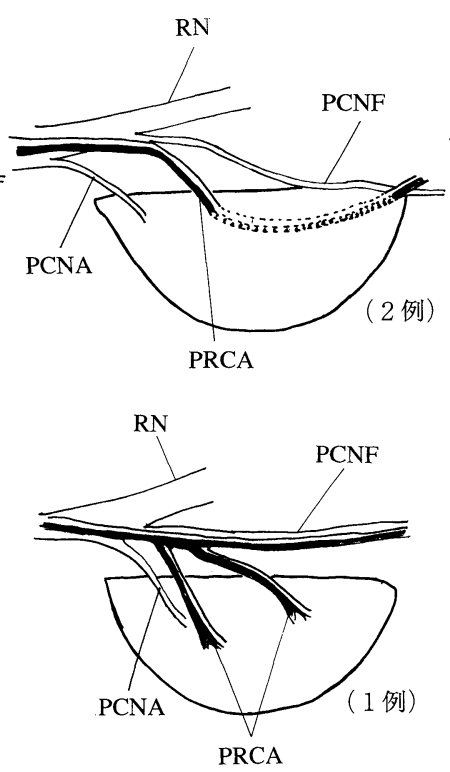
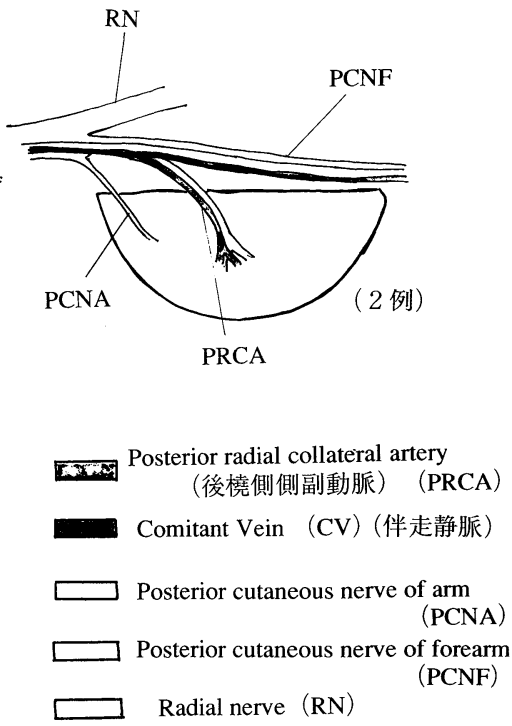

図 I Cadaver 10 症例の動静脈, 神経の走行（Lateral Upper Arm Flap における） 


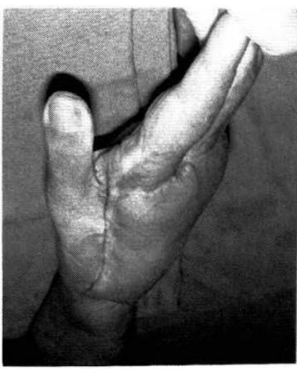

A

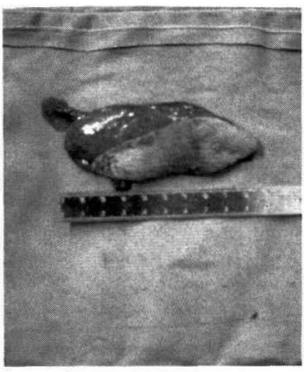

A

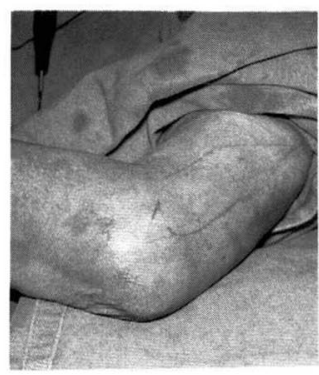

B

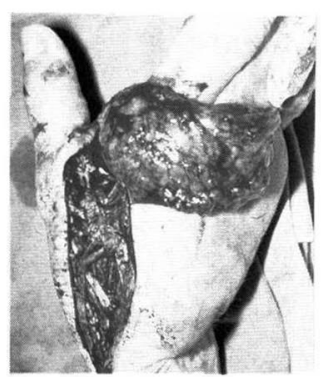

B

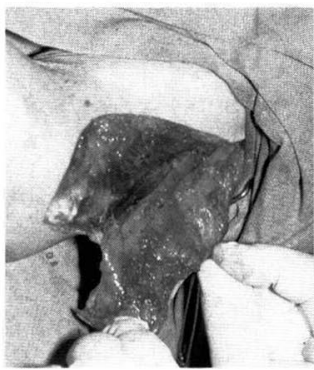

C

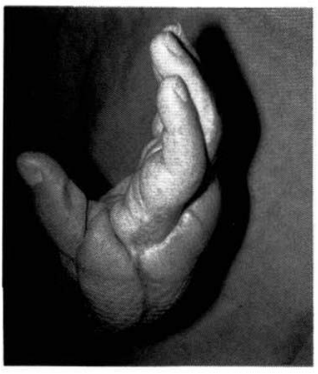

C

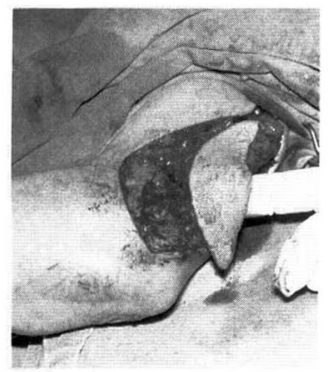

D

図 II 60 歳女性 右上腕骨顆上骨折 右手手背皮獻欠損 右手指拘縮・母指内転拘縮

A 術前母指内転拘縮

B Flapのデザイン

C 皮弁挙上(前面より)

$\mathrm{D}$ 皮弁挙上(前・後面より)

$\mathrm{E}$ 皮弁採取

F 皮弁移植

$\mathrm{G}$ 術後 3 力月

を用いることが多い. Lateral Upper Arm Flap は支 配動静脈が伴走している，知覚神経を含んでいるため 知覚皮弁として利用できる. 又, 皮弁の採取が比較的 容易で PRCA が常に存在するということで, 大きな皮 弁がとれない点を除けば優れた皮弁である. 私達は 10 例の Cadaver を調へ，皮弁の支配動脈である PRCA が常に存在し動脈径平均 $1.47 \mathrm{~mm}$, 静脈径平均 1.72 $\mathrm{mm}$ と比較的大きかった. PRCA は筋間中隔から出て くる橈骨神経が確認できれば容易に発見された．皮弁 を支配する PCNA は，PRCA に伴走するものと離れ て皮弁に入るものがあるがすべて存在し, 知覚皮弁と して十分に可能であることがわかった。臨床例は 3 例 と少ないがすべて手掌部皮膚欠損, 母指の内転拘縮と 手に用い良好な結果を得た. donor 側は直接縫合でき たが前腕外側部に 2 例は知覚低下, シベレを生じた。 しかし特に支障をきたすものではなかった。このうち 1 例は PCNA をPRCA をのこすため一時的に切離し 再び縫合した症例も含んでいる.

\section{ま と め}

1. Cadaver 10 例, 臨床 3 例に Lateral Upper Arm Flap を施行し検討した.

2. PRCA の動脈径は平均 $1.47 \mathrm{~mm}$, 静脈径は 1.72 $\mathrm{mm}$ と十分の大きさであった.

3. PRCA, PCNA はすべてに存在し, 解剖学的 Variationが少なかった.

4. 臨床例は 3 例と少なかったが動脈径は $1.2 \mathrm{~mm}$, $1.5 \mathrm{~mm}, 1.8 \mathrm{~mm}$ と大きく吻合に支障はなかった. Donor 側は直接縫合できたが 2 例は前腕外側に知覚 低下, シビレを残した。

\section{文献}

1) Katsaros J et al : The lateral upper arm flap ; anatomy and clinical applications. Ann Plost surg $12:$ 489-500, 1984.

2）中島英親：静脈皮弁の検討, 形成外科 32 (1) : 1120, 1989.

3) Song $\mathrm{R}$ et al : The one stage reconstructions; the upper arm flap.clin plost Surg 6;27-35, 1982. 